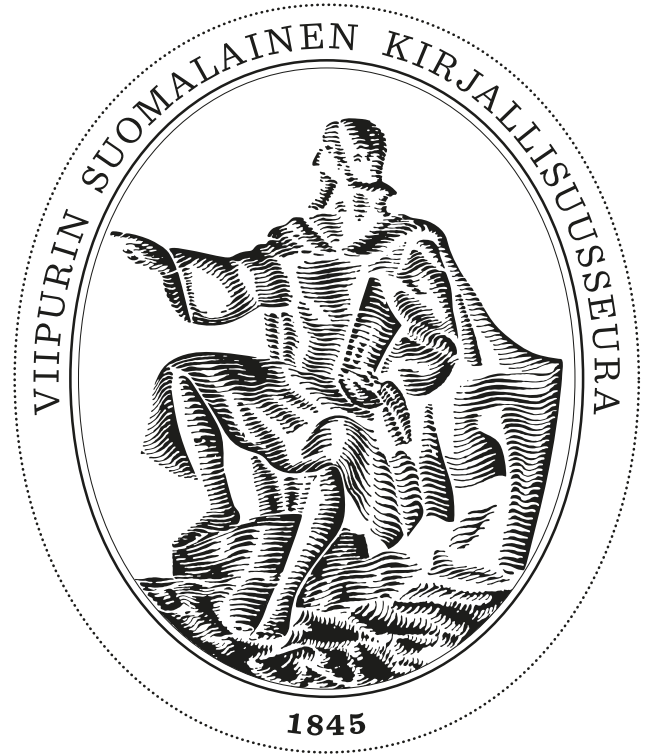

VIIPURIN SUOMALAISEN

KIRJALLISUUSSEURAN

TOIMITTEITA

(18)

Muuttuvien tulkintojen Viipuri 
Kansikuva: Osa Severin Falkmanin vuonna 1886 tekemästä öljymaalauksesta Kaarle Knuutinpoika Bonde lähdössä Viipurin linnasta Tukholmaan kuninkaanvaaliin 1448. Karl Knutson Bonde på väg från Viborgs slott till kungavalet i Stockholm 1448.

Kansallisgalleria/Kirsi Halkola. Ateneumin taidemuseo.

Viipurin Suomalaisen Kirjallisuusseuran Toimitteita osa 18 Muuttuvien tulkintojen Viipuri

Toimittaneet:

Anu Koskivirta (osan päätoimittaja),

Pentti Paavolainen (sarjan päätoimittaja),

Sanna Supponen (sarjan toimitussihteeri)

Kuvatoimitus:

Risto Marjomaa

Graafinen suunnittelu \& taitto:

Eemeli Nieminen, www.eemelinieminen.fi

ISBN: 978-952-67216-3-7 (Toimite 18, PDF)

ISSN: 1236-4304 (Sarja)

Painettu: 2016, Juvenes Print

Painosmäärä: 200 kpl

2. korjattu painos.

Julkaisija: Viipurin Suomalainen Kirjallisuusseura, Helsinki 


\section{Viipurin kulttuurielämä Vanhan Suomen aikana: historiankirjoitusta ja tutkimusideoita}

Tässä artikkelissa tarkastellaan Vanhan Suomen ajan (1710-1811) Viipurin kulttuurihistorian tutkimustilannetta ja tarjotaan uusia tutkimustehtäviä paikkaamaan olemassa olevan tutkimuksen aukkoja tai ajanmukaistamaan sen näkökulmia. Vuonna 2013 julkaistussa Yrjö Kaukiaisen, Risto Marjomaan ja Jouko Nurmiaisen toimittamassa teoksessa Viipurin läänin historia IV: Vanhan Suomen aika on muun ohella esitetty ajanmukainen yhteenveto Viipurin kaupunkikulttuurin osa-alueista eikä siinä olevaa faktatietoa ei ole tässä tarpeen toistaa. Toisaalta kyseisessä laajalle yleisölle suunnatussa suurteoksessa ei ollut mahdollista pohtia Viipurin kaupunkia koskevia historiografisia kysymyksiä tai ongelmakohtia, saatikka ehdottaa uusia, vaihtoehtoisia tutkimustapoja. Tämä aukko täytetään tässä artikkelissa.

Seuraavassa luodataan Vanhan Suomen ajan Viipurin kulttuurihistorian tutkimustilannetta pitkällä aikavälillä. Tavoitteena on selvittää tutkimuksen taustatekijöitä ja aihevalintoja ja arvioida niiden julkilausumattomia tavoitteita ja metodisia perusteluja.

\section{0-LUVUN TUTKIJAT: VON KNORRING, AKIANDER JA LAGUS}

Kuten monen muunkin Vanhan Suomen historian osa-alueen, myös Viipurin 1700-luvun kulttuurihistorian tutkimus alkaa Frans Petter von Knorringin kuvauksesta Gamla Finland eller det fordna Wiborgska gouvernementet vuodelta 1833. Teoksessa esitetään tilastollis-maantieteellinen katsaus Vanhan Suomen aikaan ja sen tueksi runsaasti kuvernementin pääkaupunkia Viipuriakin koskevaa asiatietoa kaikilta hallinnonaloilta. ${ }^{1}$ Kertovaa tai problematisoivaa historiantutkimusta teos edustaa enintään välillisesti: se luo rehabilitoivan yleiskatsauksen Vanhan Suomen oloista, ruotsiksi painettuna ensimmäisen laatuaan. Vanhan Suomen ja muun Suomen yhdistämisen (1812) jälkeisinä vuosikymmeninä tällainen Viipurin läänin erityisoloja kuvaava hakuteos oli tarpeellinen: siitä hyötyivät etenkin suuriruhtinaskunnan virkamiehet, mutta myös suuri 
yleisö. Kulttuurihistoriallisiksi voidaan lukea von Knorringin teoksen ensimmäisen osan kuvaukset esimerkiksi kirkon - myös kreikkalais-venäläisen sekä koululaitoksen asemasta ja toiminnasta.

Ensimmäinen Vanhaan Suomeen sekä Suomen ja Venäjän välisten suhteisiin erikoistunut akateemisesti ansioitunut tutkija oli Matthias Akiander. Kulttuurihistoriallisesti tärkeitä ovat edelleen hänen kaksi perusteostaan Skolverket inom fordna Wiborgs och nuvarande Borgå stift (1866) sekä yli 1000-sivuinen hiippakunnan paimenmuisto Herdaminne för fordna Wiborgs och nuvarande Borgå stift (1868-69). Skolverket-teos sisältää kouluja koskevia asetuksia, ohjesääntöjä ja viranomaispäätöksiä sekä tietoja kaikkien koulujen historiasta ja opettajakunnasta julkaisuajankohtaan saakka. Henkilöhistoriallisesti tärkeästä Akianderin paimenmuistosta on vuonna 2008 julkaistu Iikko B. Voipion toimittama uudistet-

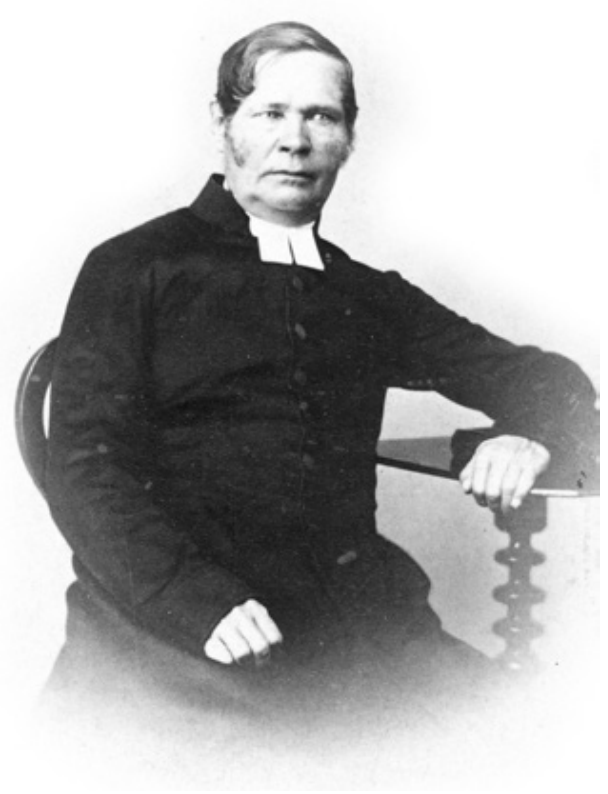

Venäjän kielen ja kirjallisuuden professori, historiantutkija Matthias Akiander 1860-luvun alussa. tu ja neliosaiseksi laajennettu laitos Östra Finlands herdaminne.

Akianderin kaksi teosta luovat etenkin henkilöhistoriallisen kontekstin koko itäisen hiippakunnan kirkolliselle kulttuurille. Tämän kulttuurin vuosisatainen jatkuvuus ja suhteellinen riippumattomuus maallisesta esivallasta poikkeavat perustavanlaatuisesti kuvasta, joka matrikkelien ja muiden henkilöhistoriallisten tietolähteiden avulla muodostuu seudun muusta virkakunnasta.

Ennen kuin varsinainen kaupunkihistoriallinen tutkimus käynnistyi, varhaismodernin ajan Viipurin historian tunnetuin popularisoija oli tohtori ja Viipurin kymnaasin lehtori Gabriel Lagus. Hän julkaisi linnan 6oo-vuotisjuhliin vuonna 1893 ruotsiksi ja suomeksi ensimmäisen osan sarjastaan Ur Wiborgs historia (Kuvauksia Wiipurin historiasta). Kaksiosaisen sarjan myöhempi osa ilmestyi vuonna 1895. Näissä teoksissa käsitellään kaupungin vanhaa historiaa, erityisesti tarinoita ja kertomuksia Ruotsin vallan ajasta. ${ }^{2}$

Laguksen teokset ovat rinnakkaisia muillekin näihin aikoihin huomiota herättäneille hankkeille paikallisen historian rekonstruoimiseksi. Niihin kuuluivat 1880-luvulla arkkitehti Jac. Ahrenbergin suurisuuntaiset linnan restaurointisuunnitelmat ja vuosisadan vaihteessa toteutuneet pyrinnöt Viipurin museon perustamiseksi ja patsaan pystyttämiseksi linnan perustajalle Torkkeli Knuutinpojalle. ${ }^{3}$

Yhteistä näille kaikille oli Viipurin historian Ruotsin aikaisten vaiheiden korostaminen ja miltei täydellinen vaikeneminen Vanhan Suomen venäläisestä 


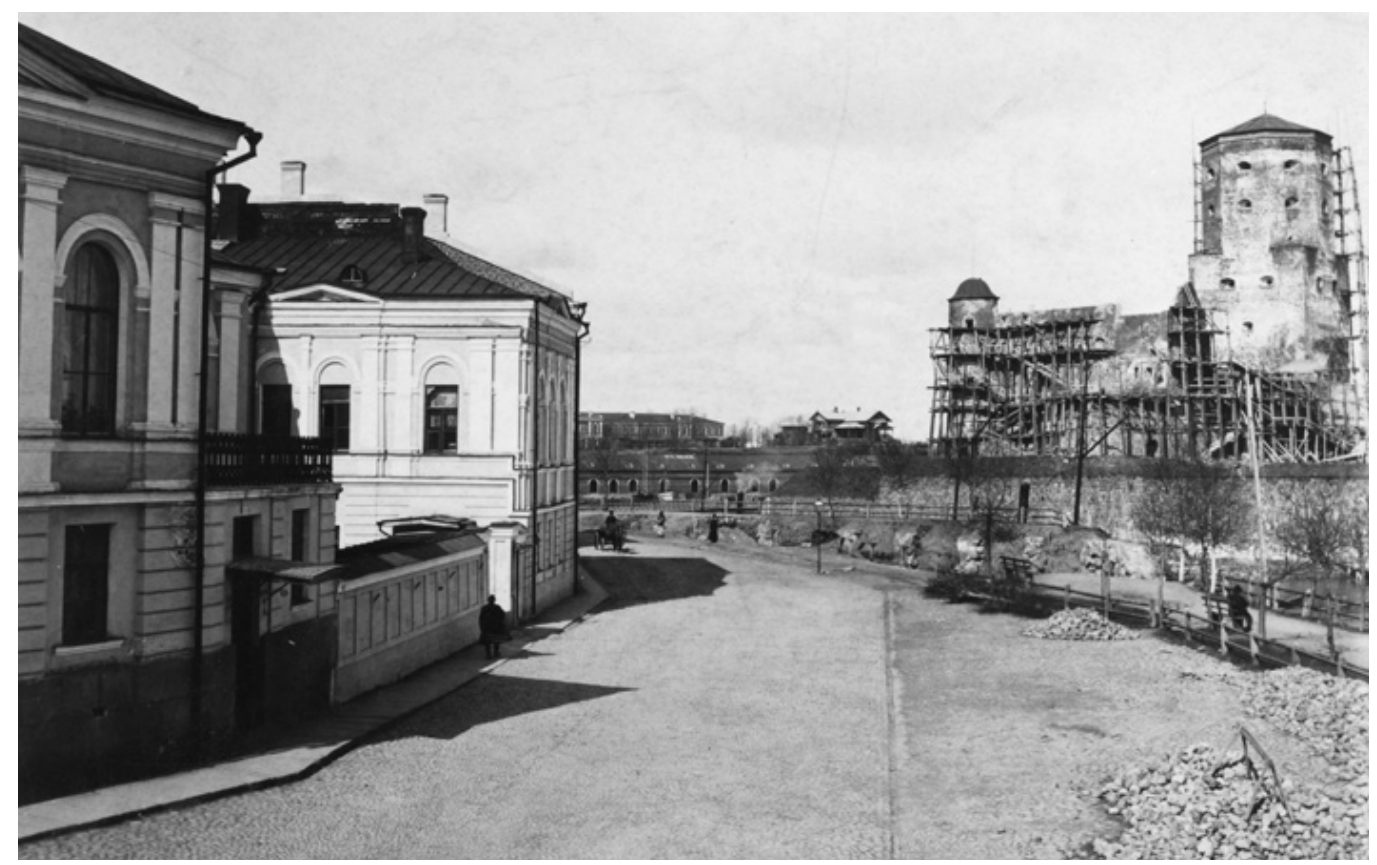

Viipurin linnaa korjataan 600-vuotisjuhlia varten 1890-luvun alussa. Vasemmalla vanha Hackmanin talo.

kaudesta. Kyseessä oli osin vastareaktio Venäjän viranomaisten tuolloisille yhdenmukaistamistoimille Suomessa ja keisarin vuonna 1888 antamalle päätökselle jättää Ruotsin vallan ajan tärkein historiallinen muistomerkki, Viipurin linna, venäläisten sotilasviranomaisten hallintaan.

\section{SORTOKAUSIEN HANKALA VENÄLÄISSUHDE: RUUTHIN JA BORODKININ TULKINNAT}

Suomalaisen tutkimuksen yleiskäsitykselle Vanhan Suomen ajan Viipurin kulttuurihistoriasta loi perustan lähes sadan vuoden ajaksi J. W. Ruuthin Viipurin kaupungin historian 2. osa (ruotsiksi 1906, suomeksi 1908). Esitys perustuu lähes yksinomaan ei-venäläisiin lähteisiin, ennen kaikkea kaupungin hallinnon omiin pöytäkirja- ja asiakirjasarjoihin. Ruuth omistaa Vanhan Suomen ajalle lähes 250 sivua, josta kaupunkirakentaminen, asemakaavat sekä julkiset ja yksityiset rakennukset saavat osakseen noin viidesosan. ${ }^{4}$

Rakennushistorian ohella Ruuth käsittelee monipuolisesti ruotsalais-saksalaisen kaupunkiporvariston omintakeista kulttuuria ja henkilöhistoriaa sekä johtavien sukujen verkostoitumista ja taloudellisia suhteita. Hän kiinnittää huomionsa "porvarillisen julkisuuden" ensi askeliin 1700-luvun lopulla: arki- 
elämään, huveihin ja aineellisen kulttuurin muoti-ilmiöihin. Kirkollista elämää, kirkkoja ja seurakuntien johtohahmoja käsitellään sangen perusteellisesti, mutta koululaitokselle ja etenkään Katariina II:n aikaisille uudistuksille Ruuth ei anna juurikaan arvoa. Aleksanteri I:n aikana vuonna 1805 perustettu kymnaasi sen sijaan nähdään tärkeäksi sivistyslaitokseksi. Monipuolisessa kuvauksessaan hän sivuaa myös porvariston aatemaailman uutuuksia vapaamuurariudesta pietismiin siinä kuin ruotsinkielisten ja saksankielisten sukujen intressejä ja ristiriitojakin.

Aikakauden muun Vanhan Suomen oloja koskevan tutkimuksen tapaan Ruuthille on ominaista eräänlainen pysyvä konfliktiasetelma venäläisen esivallan ja paikallisyhteisön välillä, minkä hän ulottaa myös kulttuurin alueelle. Etenkin sotilasviranomaiset ja kuvernöörit esitetään yleensä mielivaltaisina ja kielteisessä valossa eikä venäläistä kaupunkiasujaimistoa mainita juuri ollenkaan. Rappio ja taantuminen uhkaavat stereotyyppisesti aina venäläisten valtaa pitävien alaisuudessa, mutta kehitystä vastaan taistellaan Viipurin ruotsalais-saksalaisen sivistysperinnön voimin menestyksellisesti vuoteen 1812 saakka.

Ruuthin näkökulmat heijastelevat 1900-luvun alun saksan- ja ruotsinkieliselle ajattelulle ominaisia käsityksiä siitä, että valitut, alkuperältään germaaniset ja rahvaan yläpuolella olevat yhteiskuntaryhmät toimivat historian eri vaiheissa kulttuurin tuottajina ja ylläpitäjinä (Kulturträger). Niiden vastakohtina olivat alempiarvoiset, vielä sivistymättömät ja kulttuurittomat yhteiskuntaryhmät, jotka määrittyivät etnisesti tai kielellisesti. Viipurissa tällaisiksi ryhmiksi voitiin ajatella suomalainen ja venäläinen palvelusväki ja käsityöläiset sekä venäläiset sotilaat ja kaupustelijat.

J. W. Ruuthin jälkeen Viipurin ja Vanhan Suomen oloja käsiteltiin laajasti Mihail Borodkinin (1852-1919) moniosaisessa venäjänkielisessä Suomen historiassa Istorija Finljandii, joka oli jaettu osiin hallitsijoiden mukaan. Sen osat Pietari I:stä Aleksanteri I:een ilmestyivät vuosina 1909-1912. Borodkin kuului kenraalikuvernööri Bobrikovin uskollisiin kannattajiin, minkä vuoksi hän oli Suomessa huonossa maineessa jo vuosisadan alussa. Suomen Venäjään liittämisen 100-vuotisjuhlinnan vuosina ilmestynyt historiateos ei asiaa ainakaan parantanut, koska teoksen yleinen sanoma kohdistui suomalaista "separatismia" vastaan. Borodkin esittää Viipurin historiasta runsaasti venäläisiin lähteisiin ja kirjallisuuteen perustuvia tietoja alkaen kaupungin valloituksesta vuonna 1710. Borodkinin historiasarja tarkastelee 1700-lukua yli tuhannen sivun ja Aleksanteri I:n aikaa yli 600 sivun verran. Vaikka hän käsittelee ennen muuta Vanhan Suomen ja muun Suomen suhteisiin liittyvää sotahistoriaa ja Venäjän hallintotoimia, sarjan läpäisevänä teemana on näiden "rajamaiden" kulttuurinen integroiminen Venäjän keisarikuntaan. ${ }^{5}$ 


\section{VIIPURI-TUTKIMUKSEN SUUNTAUKSIA ITSENÄISYYDEN AJAN ALKUVUOSIKYMMENINÄ: RAKENNUS-, KOULU- JA YRITYSHISTORIAA}

Bobrikovin vuosien kotimaisen historiankirjoituksen tendenssi, jonka mukaan kaikki "venäläiseen vaikutukseen" viittaavat ilmiöt kaikkina aikoina nähtiin suomalaisen kansallisen kulttuurin kannalta kielteisiksi ja vahingollisiksi, jatkui ja voimistui itsenäisessä Suomessa. Tämä koski myös Vanhan Suomen aikakautta. Viipurin historiasta nostettiin mieluusti esille Ruotsin vallan ajan sotaisuuksia Venäjää vastaan ja kaupungin asemaa läntisen kulttuurin etuvartiona itää vastaan. 1920-1930-lukujen sotahistoriaa ja suomalaisen talonpojan - läntistä - historiaa suosiva suuntautuminen ei juuri antanut sijaa 170o-luvun Vanhan Suomen tai Viipurin kulttuurin erityispiirteille muutoin kuin lahjoitusmaiden historian nostamisena esimerkiksi venäläisten sortotoimista.

Mielenkiinto Ruotsin 1700-luvun historiaan ja Kustaa III:n aikakauteen eräänlaisena suomalaisena "esinationalismin" nousukautena antoi toisaalta aihetta Katariina II:n aikakauden arvostamiseen Venäjän historiassa. Viipurilainen arkkitehti Juhani Vikstedt (Viiste) sisällytti teokseensa Suomen kaupunkien vanhaa rakennustaidetta (1926) ensimmäisenä yleisesityksenä runsaasti esimerkkejä Viipurin ja Vanhan Suomen kaupunkien 170o-luvun loppupuolen rakennuksista. ${ }^{6}$

Arkistoaineistojen parissa työskennelleet historiantutkijat paneutuivat 1930-luvun kuluessa uudella innolla Vanhan Suomen viranomaisten kielellisesti hankalaan (ruotsi, saksa ja venäjä) alkuperäisaineistoon, joka oli koko sotien välisen ajan vielä osaksi järjestämättä. Viipuriin vuonna 1933 noussut arkkitehti Uno Ullbergin suunnittelema uusi monumentaalinen maakunta-arkisto vakiinnutti historiantutkimuksen näkyväksi osaksi kaupunkikuvaa. Maakunta-arkiston johtaja Ragnar Rosén kuului niihin kielitaitoisiin tutkijoihin, jotka ottivat Vanhan Suomen aikakauden ja aineistot tutkimuskohteikseen, vaikkei hän erityisesti paneutunutkaan Viipurin 1700-luvun aihepiireihin.

Harvoja Viipurin kulttuurin perustutkimuksia 1930-luvulta edustaa Maija Raijasen väitöskirja Vanhan Suomen koulut I vuodelta 1940.7 Teoksessa sijoitetaan ensimmäistä kertaa koululaitoksen uudistukset laajemman valtakunnallisen kokonaisuuden osaksi ilman aiemmin yleistä vähättelevää J. W. Ruuthin ja hänen aikalaistensa perusasennetta.

Kuvernementtikaupunkina Viipuri oli koululaitoksen uudistuksissa ratkaisevassa asemassa. Täällä esimerkiksi toteutettiin papiston vastustuksesta huolimatta venäläisen hallintomallin mukainen julkisten koulujen sekularisointi. Uudet niin kutsutut kansakoulut ja muutkin oppilaitokset - uutuutena tyttökoulut - jäivät kirkon ja tuomiokapitulia vastaavan konsistorin valvonnan ulottumattomiin. Katariina II:n aikaista koulu-uudistusta arvosteltiin myös Ruotsin puolella rajaa: muun muassa Henrik Gabriel Porthan esitti siitä ja 
sen oppilaista erittäin kielteisiä arvioita. ${ }^{8}$ Vanhan Suomen ja muun Suomen yhdistämisen jälkeen Porvoon piispa Magnus Alopaeus yritti voimaperäisesti lakkauttaa Viipurin kuvernementin saksankielisen koululaitoksen ja siirtää sen tuomiokapitulinsa alaisuuteen. Viipurin läänin koulujen ylitarkastaja Gabriel Melartinin onnistui lykätä päätöstä lukuisten komiteoiden selvitettäväksi, ja vasta vuonna 1842 Viipurin kymnaasin opetuskieli vaihtui saksasta ruotsiksi.

1930-luvun ilmapiirissä syntynyt, Viipurin kauppahuoneiden porvarillista kulttuurimuotoa laajasti kuvaileva ja osin ihailevakin klassikkoteos oli kirjailija Örnulf Tigerstedtin vuonna 1940 ilmestynyt Huset Hackman. En wiburgensisk patriciersläkts öden 179o-1879 I. (suomeksi Kauppahuone Hackman samana vuonna, II osa 1952). Kauppahuoneen varhaisvaiheiden esittelyllä on huomattavia kirjallisia ansioita, ja se perustuu laajasti säilyneisiin perheen ja yrityksen arkistolähteisiin. Kuvauksessa nousee esille ennen muuta Viipurin porvariston monikielinen, kansainvälinen kulttuurimuoto ja sen taloudellinen perusta koko Itä-Suomessa. ${ }^{9}$

\section{TOISEN MAAILMANSODAN JÄLKEISET VUOSIKYMMENET: UUDET ARKISTOT JA NIISTÄ NOUSEVAT TUTKIMUSTEEMAT}

Talvisodan jälkeen keväästä 1940 ja uudelleen Viipurin menettämisen jälkeen 1944 kaupungin historiaa ja kulttuuria voitiin Suomessa vaalia muistojulkaisuissa, paikallishistoriallisissa tutkielmissa, muistelmissa ja kaunokirjallisissa esityksissä. Tällöin 1700-luvun loppuvuosikymmenillä pystytetyt kirkot ja muut rakennukset nostettiin olennaisiksi kulttuuriperinnön osiksi muiden aikakausien monumenttien rinnalle. Tulevien julkaisujen ja kuvateosten esikuvaksi muodostui Olavi Paavolaisen toimittama Karjala, muistojen maa vuodelta 1940. Siinä huomioitiin Vanhan Suomen aikainen Viipuri. Aikakausi niin ikään oli varsin näkyvästi esillä Juhani O. V. Viisteen kulttuurihistoriallisessa kuvateoksessa Viihtyisä vanha Viipuri (I painos 1943). Teoksella oli kuvaava alaotsikko: Kulttuurimuistojen, kuulujen puistojen, kauniiden tornien kaupunki. Monrepos'n puisto oli muodostunut tunnetuksi matkailukohteeksi ja sen historiaa ja erityispiirteitä oli suomalaiselle yleisölle esitellyt ensimmäisenä K. K. Meinander suurteoksen Herrgårdar i Finland kolmannen osan Karjala-osiossa vuonna 1929. Ruuth ei näet käsitellyt Monrepos'n puistoa ja sen historiaa. Syynä lienee se, että kartano sijaitsi hänen historiateostensa kirjoitusajankohtana Viipurin maaseurakunnan alueella. ${ }^{10}$

"Evakkoperspektiivi" ja riippuvuus Suomen puolelle pelastetuista ja vasta vähitellen Mikkelin maakunta-arkistossa tutkijoiden käyttöön saaduista aineistoista leimasivat 1950-1960-lukujen Viipuri-julkaisuja Suomessa. 170o-lu- 
vun akateemista viipurilaisuutta ja sen henkilöhistoriaa Turun akatemian näkökulmasta tutki Viljo Nissilä (1953) Viipurilaisen osakunnan historiassaan vuoteen 1827 saakka." Nissilä korjaa esimerkkien avulla aikaisemmin vallalla olleet käsitykset Vanhasta Suomesta kotoisin olevien ylioppilaiden alhaisesta sivistystastosta ja taipumuksista venäläisyyden myötäilijöiksi. Jo aikaisemmin Yrjö Blomstedt oli eräässä artikkelissaan esitellyt "Suomesta kotoisin olevat ylioppilaat Tarton yliopistossa 1802-1852". Näistä huomattavan moni oli kotoisin Viipurista ja Vanhan Suomen alueelta, mitä Venäjän oppilaitosjärjestelmän uudistus vuonna 1802 oli edellyttänytkin. ${ }^{12}$

Viipurin vuonna 1805 avatun kymnaasin oppilasmatrikkelin taustatietoineen julkaisivat 1961 Harald Hornborg ja Ingegerd Lunden Cronström. ${ }^{13}$ Uusi saksankielinen kymnaasi oli kaupungin sivistyslaitoksista huomattavin ja samalla kaupungin koulutetun akateemisen eliitin tärkeä kokoontumispaikka. Sen opettajakunta edusti aikansa pätevintä huippua: alkuun monet tohtorin tutkinnon suorittaneista opettajista tulivat Saksan yliopistoista. Tämän kirjallisesti tuottoisan opettajakunnan ympärille Sven Hirn konstruoi oman "Viipurin romantiikan" aikakauden "Turun romantiikan" varhaiseksi, 1810-luvun taitteeseen ajoittuneeksi vastineeksi. Vuonna 1959 ilmestynyt "Viborgsromantiken" oli Hirnin ensimmäinen laaja artikkeli muun kuin suomenkielisen kotimaisen kirjallisuuden tutkimuksen alalta. ${ }^{14}$

\section{0-1980-LUVUT: UUDISTUNEEN PERUSTUTKIMUKSEN VUOSIKYMMENET}

Sven Hirnin toinen Vanhan Suomen ajan historiografiassa uraa uurtanut Viipuri-tutkimus oli laajaan lähdeaineistoon pohjautunut Teater $i$ Viborg 1743-1870 (1970). Teoksessa käydään läpi kaupungin vanha teatterihistoria ja sen ohessa valotetaan kokonaisvaltaisesti muutakin kaupungin kulttuurielämää. ${ }^{15}$ Teatteriseurueet, esitykset ja näytelmät sitoivat Viipurin saumattomasti Itämeren provinssien kaupunkien ja Pietarin saksankielisen porvariston maailmaan. ${ }^{16}$ Vuoden 1812 jälkeen tilanne muuttui: Viipurin saapui yhä useammin seurueita Ruotsin ja Suomen puolelta ja esitysten kieleksi vaihtui vähitellen ruotsi.

1970-luvulla tuotettiin Erkki Kuujon johdolla J. W. Ruuthin kaupunkihistorian Vanhan Suomen aikaa käsittelevän osan uudistettu ja laajennettu laitos Viipurin kaupungin historia $3,1710-1812$ (1975). ${ }^{17}$ Se ei varsinaisesti kajonnut Ruuthin aikaiseen historiakuvaan, vaikka 70 vuoden aikana ilmestyneet uudet tutkimukset ja kirjoitusajankohdan paikallishistorioiden normaalikäytännöt otettiinkin huomioon. Viljo Nissilän aloitteesta perustettiin 1976 uusi Viipuri-tutkimusten sarja Viipurin Suomalaisen Kirjallisuusseuran Toimitteita. Sen 
osassa 2 (1977) julkaistu professori Otto-I. Meurmanin Viipurin arkkitehteja käsittelevä artikkeli tarkasteli myös 170o-luvun kuvernementinarkkitehtejä. Saman sarjan osassa 6 (1983) Meurman kirjoitti laajan yhteenvedon Viipurin kirkkojen rakennushistoriasta. ${ }^{18}$

Viipurin kirkollisen kulttuuri- ja henkilöhistorian merkkiteoksia olivat 1970-luvun puolivälissä ilmestyneet Kyösti Väänäsen Pappissivistys Vanhassa Suomessa sekä Vanhan Suomen papiston matrikkeli. ${ }^{19}$ Molemmissa teoksissa täsmennetään olennaisesti tietoja Vanhan Suomen papiston oppineisuudesta ja henkisestä tasosta samoin kuin seurakuntien oloista. Viipurin papisto oli hiippakuntaa vastaavassa konsistoripiirissään luonnollisesti keskeisessä asemassa koko 170o-luvun ajan.

Suomessa saatavilla olleiden lähteiden ja kirjallisuuden perusteella 1970-80-luvuilla tutkittiin myös 1700-luvun linnoitusrakentamisen sekä Viipurin ja muun Vanhan Suomen kaupunkien kirkkojen ja muiden julkisten rakennusten arkkitehtuurin historiaa (Rainer Knapas, Ulla-Riitta Kauppi). ${ }^{20}$ Suomen taidehistorian perusteokseksi toimitetun kuusiosaisen sarjan Ars-Suomen taide (1987-1990) vuonna 1988 ilmestyneessä toisessa osassa esiteltiin muun Suomen rakennusmuistomerkkien kanssa tasaveroisina Vanhan Suomen kaupunkien rakennuskulttuuri, asemakaavat, linnoitukset, samoin kuin Viipurin kirkot ja julkiset rakennukset. Kirkkorakennusten historiankirjoitusta täydensi vielä vuonna 1989 venäjäksi julkaistu venäläiseen aineistoon perustuva Juri Küttnerin tutkielma Viipurin Kristuksen Kirkastumisen katedraalin syntyvaiheista 1780- ja 1790-luvuilla. ${ }^{21}$ Siinä esitettiin ensimmäinen luotettava selvitys katedraalin arkkitehtuurista ja sen merkityksestä paitsi venäläisessä yhteydessään myös monialaisesti kulttuurielämässä vaikuttaneen N. I. Lvovin tuotannossa.

\section{NEUVOSTOLIITON ROMAHTAMISEN JÄLKEINEN SUOMEN-, RUOTSIN- JA SAKSANKIELINEN VIIPURI-TUTKIMUS}

Neuvostoliiton valtion ja valtiomuodon vaihduttua vuoden 1991 lopulla Venäjän federaatioksi suomalainen Viipuri-tutkimus elpyi. Yhteydet Venäjälle ja sikäläisten arkistoaineistojen käyttö helpottuivat samalla, kun Viipurissa lisääntyi kiinnostus oman kaupungin historiaa ja sen muistomerkkejä kohtaan. Linnan 700-vuotisjuhla vuonna 1993 heijasteli henkistä muutoskautta: sen yhteydessä rehabilitoitiin näkyvästi sekä kaupungin keskiajan ja varhaismodernin ajan ruotsalainen historia että suomalainen 1800-1900-lukujen historiavaihe. Näkyvimpänä symbolisena eleenä oli vuonna 1948 poistetun Torkkeli Knuutinpojan patsaan uudelleen pystytys entiselle paikalleen linnan sillan kupeeseen. ${ }^{22}$ Viipurin Vanhan Suomen aikakin nousi erityisesti esille Ulla-Riitta Kaupin ja 


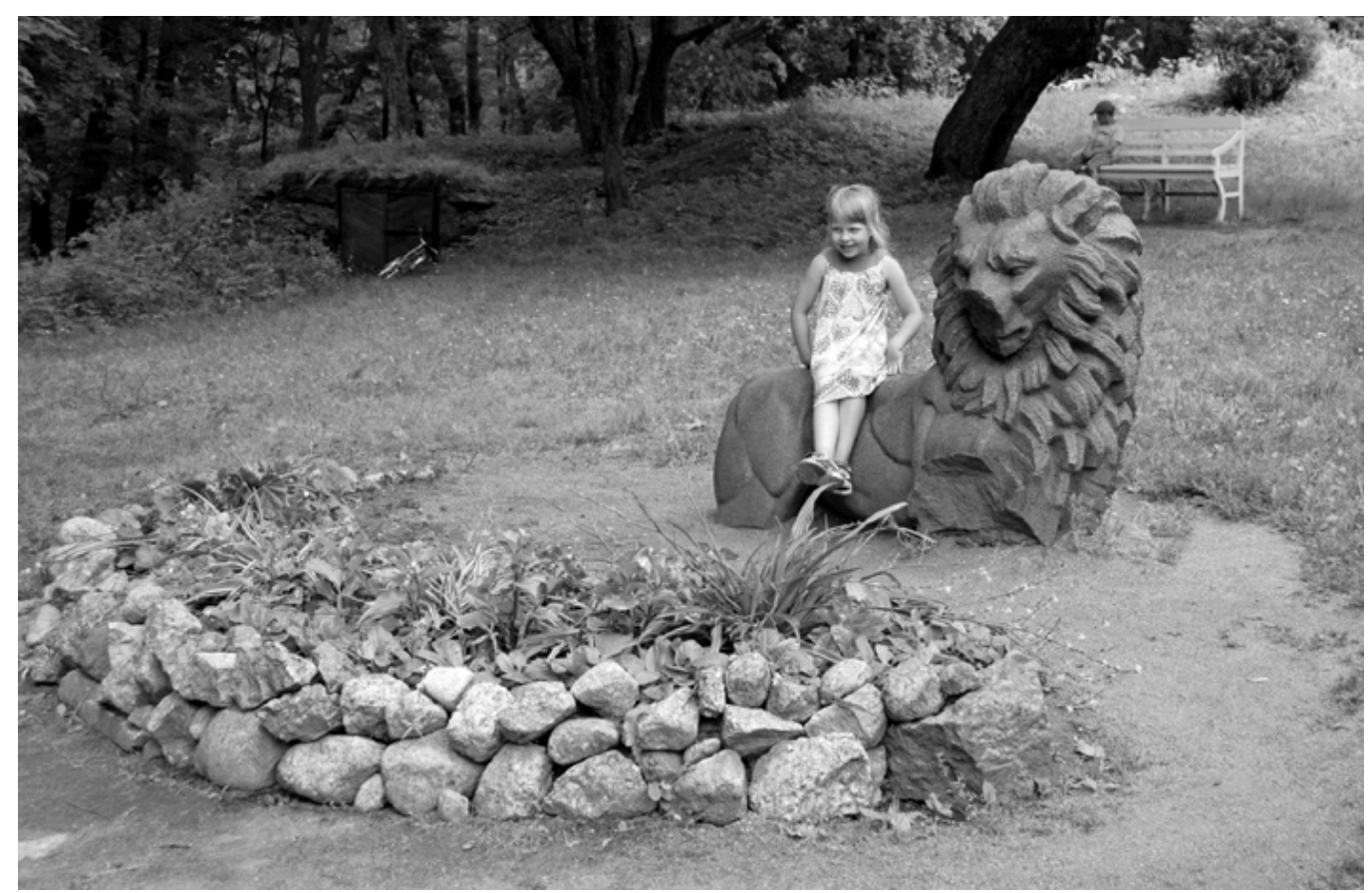

Gunnar Finnen Suomen itsenäisyyden 10-vuotisjuhlaa varten veistämä leijonapatsas sijoitettiin aluksi Tervaniemeen paikalle, josta oli itsenäisyyden alussa poistettu keisari Pietari I:n patsas. "Suomen leijona" poistettiin sijaltaan jatkosodan jälkeen. Nykyiselle paikalleen Monrepos'n puistoon leijonapatsas siirrettiin 1980-luvun lopulla sen jälkeen, kun se oli löytynyt puiston lähistöltä osin maahan haudattuna.

Mihail Miltšikin suomalais-venäläisen yhteistyön tuloksena syntyneessä, vuonna 1993 ilmestyneessä kirjassa Viipuri. Vanhan Suomen pääkaupunki. Teoksessa esiteltiin runsaasti sekä uutta teksti- ja kuva-aineistoa Venäjän arkistoista että jo aiemmin tunnettuja suomalaisia lähteitä. ${ }^{23}$

Myös aate- ja sivistyshistoriallinen tutkimus virkosi. Saksankielisen Viipuri-historiografian perinnettä jatkoi vuonna 1993 ilmestynyt Robert Schweitzerin perustavaa laatua oleva tutkielma Viipurin saksalaisista, Die Wiborger Deutschen. Myöhemmin Schweitzer on jatkanut paneutumistaan "Viipurin romantiikan" aikakauteen ja sen saksankielisiin edustajiin muun muassa Viipurin koulujen vuosijulkaisuja käsittelevässä artikkelissaan "Die Fibeln der Wiburger Aufklärung" (1996) ja August Thiemen "Finnland"-runoelman (1808) monikielisessä, kommentoidussa käännöseditiossa vuodelta 2012. ${ }^{24}$

Edelleen vuonna 1993 ilmestyi puolestaan ensimmäinen laaja tieteellinen tutkimus Monrepos'n puiston historiasta, Eeva Ruoffin Monrepos, muistojen puutar$h a .{ }^{25}$ Vuonna 2003 ilmestyi toinen Monrepos'n 1700-lukua esittelevä teos, Rainer Knapaksen Monrepos. Ludwig Heinrich Nicolay och hans värld i 17oo-talets ryska 
Finland. ${ }^{26}$ Teoksen tavoitteena oli esitellä Monrepos'n kokonaisuutta sekä yleiseurooppalaisena että Venäjän hovin vaikutuspiirissä syntyneenä ja Suomessa toteutettuna synteesinä aikakautensa taidekäsityksistä. Monrepos'n historiaa ja sen Suomessa säilyneitä arkisto- ja kirjakokoelmia esiteltiin 199o-luvulta alkaen useissa Helsingin yliopiston kirjaston järjestämissä näyttelyissä julkaisuineen.

Valtionarkeologi C.-J. Gardbergin ja valokuvaaja P.-O. Welinin kirja Viipuri kivestä rakennettu kaupunki (myös ruotsiksi, Viborg - stad i sten, 1996) taas esitteli uusissa valokuvissa näkyvästi muun muassa 1700-luvun rakennusmuistomerkkejä. ${ }^{27}$ Suomalaisten arkkitehtien Juhani Viisteen ja Otto-I. Meurmanin aloittama arkkitehtuurin historian tutkimusperinne jatkui uudistettuna 200o-luvulle tultaessa. Uutta tarkennettua tietoa Viipurin 1700-luvun rakentamisesta ja rakennuksista esiteltiin muun muassa Petri Neuvosen, Tuula Pöyhiän ja Tapani Mustosen laajassa arkkitehtuurioppaassa Viipuri - Vyborg. Opas kaupunkiiin Town Guide (1999). Petri Neuvonen on kahdessakin tutkimuksessaan selvittänyt yksityiskohtaisesti vanhan kaupunginosan rakentamisen vaiheita kortteli korttelilta mukaan lukien talvi- ja jatkosotien aikaiset tuhot ja jälleenrakentamisen vaiheet. Vielä säilyneet 170o-luvun rakennukset ovat näissä teoksissa luonnollisesti näkyvästi esillä. ${ }^{28}$

1700-luvun Viipuriin liittyvää henkilöhistoriaa on jatkuvasti tutkittu ja täydennetty Suomessa. Etenkin Kansallisbiografia-hankkeeseen sisältyi lukuisia uusia elämäkertoja Viipurin kaupungin merkittävistä suvuista, porvareista ja virkamiehistä, kirjoittajinaan muun muassa Jyrki Paaskoski ja Georg Haggrén. Kansallisbiografian painettu versio ja www-sivusto antaa - ilmeisesti toimituskunnan tietoisten painotusten tuloksena - aikasempia vastaavia hakuteoksia huomattavasti enemmän tilaa itäisen Suomen ja Venäjällä uraa tehneiden virkamiesten henkilöhistorialle. Samoin erityisesti Georg Lutherin sukuhistoriallisissa tutkimuksissa on käsitelty runsaasti viipurilaisia 170o-luvun merkkihenkilöitä ja sukujen verkostoitumista. Suomen papiston ja pappissukujen kulttuuriperinteen itäinen ulottuvuus käy erittäin selvästi ilmi myös laajasta ja perusteellisesta Inkerin paimenmuistosta Herdaminne för Ingermanland, joka kuuluu alansa parhaimpiin. ${ }^{29}$

Viipurin 170o-luvun sivistyshistorian kuuluu olennaisesti kaupunkilaisten akateeminen opinkäynti. Henkilötiedot kaikista viipurilaisista ylioppilaista ja heidän akateemisista opinnoistaan sekä Turun akatemiassa että muissa yliopistoissa Ruotsissa, Saksassa ja Venäjällä sisältyvät Yrjö Kotivuoren kokoamaan ja ylläpitämään elektroniseen Ylioppilasmatrikkeliin ajalta 1640-1852, vaikka se onkin otsikoitu vain Turkua ja Helsinkiä koskevaksi. Muiden perusteellisten viitetietojen ohella matrikkeli sisältää tiedot viipurilaisten ylioppilaiden väitöskirjoista ja julkaisuista sekä keskseisimmistä elämänvaiheista. ${ }^{30}$ 
Uusimpana Viipurin 1700-luvun lopun ja 1800-luvun alkuvuosikymmenten kulttuurimuotoa kuvaavaksi tutkimuksena mainittakoon Ulla Ijäksen väitöskirja Talo, kartano, puutarha. Kauppahuoneen omistaja Marie Hackman ja hänen kulutusvalintansa varhaismodernissa Viipurissa vuodelta 2015. Se käsittelee myös laajasti viipurilaisen ylimmän porvariston maailmaa, etenkin sen materiaalista puolta, Marie Hackmanin toimintaa, hankintoja ja elämänmuotoa sekä kaupungissa että Herttualan kartanoympäristössä. ${ }^{31}$

\section{NEUVOSTOLIITON JA VENÄJÄN VIIPURI-TUTKIMUKSEN VAIHEITA}

Viipurin paikallishistoriaa venäläisenä 170o-luvun kuvernementtikaupunkina käsiteltiin 1950-luvulta 1980-luvulle matkaoppaissa ja kaupunkia esittelevissä kuvateoksissa vain ohimennen. Tapahtumista mainittiin lähinnä Pietari Suuren valloitus vuonna 1710 ja vuosisadan muistomerkeistä Monrepos. Uusi paikallishistorian, venäläisittäin "seutututkimuksen" (kraevedenie) nousukausi alkoi 1980-luvulla. Sen keskeinen henkiin herättäjä Viipurissa oli opettaja Jevgeni Kepp, joka perusti "Vanha Viipuri", Staryj Vyborg -nimisen harrastajapiirinsä 1985. Hän keräsi suuren määrän historiallista lähde- ja kuva-aineistoa ja kirjoitti paikallisiin lehtiin ja muihin julkaisuihin Viipurin historiasta ja erityisesti sen arkkitehtuurin muistomerkeistä. ${ }^{32}$

Ensimmäisen Viipurin arkkitehtuurihistoriaa esittelevän kirjasensa Kepp julkaisi vuonna 1977. Sen jälkeen Kepp laajensi jatkuvasti opaskirjojensa sisältöä. Perusteellisin, 200-sivuinen taiteellisten nähtävyyksien esittely ilmestyi vuonna 1992 (Vyborg, Hudožestvennye dostoprimetšatelnosti). ${ }^{33}$ Keppin ohella Viipurin rakennusperinnön tutkijana on 1970-luvulta alkaen toiminut arkkitehti Viktor Dmitriev. Venäläsiin arkistoaineistoihin pohjautuvissa tutkimuksissaan hän on tarkentanut kuvaa 170o-luvun jälkipuoliskon julkisten rakennusten ja sotilasrakennusten suunnittelijoista ja niiden syntyvaiheista.

1980-luvun alkuvuosista lähtien venäläisten tutkijoiden huomio kohdistui yhä enemmän Monrepos'n puiston historiaan Venäjän 1700-luvun kulttuurin osana. Avainasemassa oli arvostettu akateemikko, kirjallisuuden tutkija ja filologi Dmitri Lihatšov, joka "löysi" Monrepos'n ja sen kansainvälisen aatetaustan uudelleen ja käsitteli sitä monessa yhteydessä, etenkin puutarhataiteen historiaa Venäjällä ja Euroopassa käsittelevässä teoksessaan Poezija sadov (Puutarhojen runoutta, I painos 1982). ${ }^{34}$ Siinä Monrepos'n puistoa esitellään Venäjän tunnetuimpien keisarillisten puistojen rinnalla pohjoisena, "ossiaanisena" ja suomalaisen luonnon erityispiirteitä korostavana taideluomana, joka oli omistajansa Ludwig Heinrich Nicolayn maailmankuvan ilmentymä. Lihatšov korosti paitsi Monrepos'n "esiromantiikkaa" (romantizm) myös Ossianin laulujen ja 
muun pohjoisen mytologian mielikuvien yhdistymistä suomalaisen kansanrunouden ja Kalevalan maailmaan. Kirja on Venäjällä saavuttanut klassikon aseman ja ilmestynyt monina painoksina.

Vuonna 1984 Lihatšov otti eräässä artikkelissaan voimakkaasti kantaa Monrepos'n säilyttämisen ja suojelun puolesta. ${ }^{35}$ Tästä seurasi Venäjällä julkinen debatti Monrepos'n merkityksestä, mikä inspiroi uusia Monrepos'n historiaa koskevia tutkimuksia. Keskustelun lopputuloksena Monrepos'n virallinen status muuttui tammikuussa 1988, kun Venäjän neuvostotasavallan ministerineuvosto päätti nimetä alueen "Park Monrepos -nimiseksi historian, arkkitehtuurin ja luonnon museo-suojelukohteeksi".

Monrepos'n puiston vaiheet ja sen henkilöhistoria ovat 1990-luvulta 2010-luvulle olleet toistuvasti venäläisten tutkijoiden (muun muassa Mihail Kostolomov, Mihail Jefimov, Julia Moshnik) aiheina, joskin pääsääntöisesti varsin suppeissa julkaisuissa ja artikkeleissa. Mainitut kolme tutkijaa ovat muun muassa julkaisseet vuonna 2013 uuden, seikkaperäisesti kommentoidun käännöksen venäjäksi Ludwig Heinrich Nicolayn pitkästä runoelmasta "Das Landgut Monrepos in Finnland, 1804". Monrepos-aihepiiristä on Viipurissa julkaistu venäjäksi Julia Moshnikin ja Mihail Jefimovin toimittama laaja artikkelikokoelma, Monrepo Almanah (2010). ${ }^{36}$

Kiinnostusta on herättänyt myös paikallinen kirkollinen historia. Viipurin ortodoksisten kirkkojen ja seurakuntien historiaa vuodesta 1710 uudelle vuosituhannelle saakka käsittelee osin uusiin venäläisiin lähteisiin perustuva I. V. Trohovan kirja Tšerkovnaja istorija Vyborga i ego okrestnostej (2007). Teoksesta saa 1900-luvun alkuvuosilta ja lähdekirjallisuudestakin periytyvän venäläiskansallisen esityskonvention mukaisesti sen kuvan, että Viipuri olisi ollut täysin venäläisten ja venäjänuskoisten asuttama kaupunki 1710-luvulta lähtien. ${ }^{37}$

\section{PAIKALLISUUS, YLEISVALTAKUNNALLISUUS JA SAKSANKIELISEN MAAILMAN KULTTUURIN LAINAUTUMINEN}

Viipurin läänin historia -sarjan IV osassa kootaan muun ohella yhteen Viipurin kaupungin kulttuurihistorian yllä kuvattu yleinen tutkimustilanne, tosin esittämättä varsinaisesti uusia kysymyksenasetteluja tai tuomatta esiin uutta lähdeaineistoa. ${ }^{38}$ Tällä hetkellä 1700 -luvun Viipuria tutkittaessa on entistä paremmat mahdollisuudet luopua kansallisista tulkinta- ja ennakkomalleista, joissa kulttuuri nähdään ensisijaisesti sitoutuneena kansallisuus- ja kieliryhmiin. Tämän perusmallin mukaisesti 180o-luvun jälkipuoliskolla ja 1900-luvulla kehitettyä käsitteistöä on projisoitu ajassa taaksepäin aikakauteen, jolloin kansallisuus- ja kielikysymykset eivät olleet yhteiskunnallisesti tai valtiollisesti 
määrääviä jakolinjoja. Paikallisuus, paikallisen yhteisön tai korporaation jäsenyys tai toisaalta monikansallisen valtakunnan ja sen hallitsijan - Venäjän - alamaisuus määräsivät yksilön aseman ja toiminnan mahdollisuuksia.

Viimeistään edellä mainitun teoksen artikkelit ovat vakiinnuttaneet uudenlaista historiakuvaa, jossa ymmärretään, että Venäjänkin keskushallinto ja hallitsija pyrkivät rationaalisiin, valistuskauden filosofiaan ja aatteisiin perustuneisiin "yleistä etua" tavoitelleisiin reformeihin. Niitä tehtiin niin opetuslaitoksessa, kaupunkisuunnittelussa, sotalaitoksessa kuin oikeudenhoidossa ja verotuksessakin. Reformit ohjattiin ylhäältä käsin laatimalla lainsäädäntöä ja antamalla määräyksiä, joissa esiteltiin seurattaviksi tarkoitettuja normeja ja joissain tapauksissa myös taustalla olevia käsitteitä, kuten 170o-luvun kasvatusopillisia teorioita. Niiden toteuttamisesta paikallistasolla seurasi säännöllisesti eri intressiryhmien välisiä konflikteja, valituksia ja oikeusprosesseja. Ne on dokumentu asiakirjoihin, jotka ovat suomalaisten tutkijoiden saatavilla (esimerkiksi Viron, Liivinmaan ja Suomen oikeuskollegion aineistot Kansallisarkistossa). Käytännössä annetuista ohjeista ja määräyksistä poikettiin säännöllisesti vedoten paikallisiin erityisoloihin, perinteisiin tai taloudellisiin vaikeuksiin.

Hallinnolliseen, oikeudelliseen, sotilaalliseen tai kirkolliseen - sekä luterilaiseen että kreikkalais-venäläiseen - esivaltaan sidotut kulttuurin ilmentymät pyrittiin sovittamaan ylhäältä annettuihin muotoihin. Valvonta, raportointi ja rankaiseminen poikkeamisista lisäsivät ristiriitoja eri toimijoiden ja ryhmittymien välillä. Kaupunkiin nimitetyt kuvernöörit ja komendantit edustivat keskushallintoa julkisen vallan käyttäjinä, kaupungin porvarien omat hallintoelimet taas puolustivat omaa perinteistä itsenäisyyttään ja hallitsijoiden vahvistamia privilegioitaan.

Olemassa oli toisaalta kaupunkiyhteisön ja sen eri korporaatioiden omaehtoisia "vapaita sivistyspyrkimyksiä", joiden kohdalla vapaus merkitsi ainakin jonkinlaista riippumattomuutta kaupungin, kuvernementin tai valtakunnan hallinnosta. Tällaisia olivat esimerkiksi julkiset ja yksityiset huvit tai tanssiaiset, "klubit", vierailevien seurueiden teatteriesitykset, lukuyhdistykset ja lainakirjastot. Historiallista lähdeaineistoa on tältä alalta saatavissa lähinnä ylemmän porvariston maailmasta, joka oli 1700-luvulla "luonnostaan" monikielinen. Teatterinäytäntöjen yleisö oli sekä saksan-, venäjän- että ruotsintaitoista, ja ajoittain esitettiin amatöörivoimin näytelmiä venäjäksikin. Vierailevat teatteriseurueet esiintyivät silti pääsääntöisesti saksaksi. Näytelmien valikoima oli huomattavan laaja, mutta ilmeisesti täysin samanlainen kuin muussakin saksankielisessä maailmassa Baltian kaupungit, Pietari ja Moskova mukaan lukien. Vakavaan kulttuuriin kuuluivat suuret saksalaiset aikalaiskirjailijat, kuten Schiller tai Lessing, joiden tuotantoon saattoi tutustua tuoreeltaan myös 
Viipurissa. Hengeltään kepeämpää kirjallisuutta edusti huvinäytelmien kansainvälinen suursuosikki August Friedrich Ferdinand von Kotzebue.

Viipurin lyseon yliopettajan $\mathrm{Au}$ gust Wilhelm Tappen aloitteesta 1808 perustettu "kaupunginkirjasto", Wiburgische Stadtbibliothek, oli tyypillinen 1700-luvun lopun kaupunkiporvariston yhteishanke, joka toi tarjolle lainattavaa ajankohtaista kirjallisuutta eri aloilta, samoin aikakauslehtiä. Kirjat olivat pääasiassa saksankielisiä. Myös joitakin ranskan- ja venänkielisiä teoksia oli tarjolla, mutta ruotsinkielisiä ei yhtäkään.

Paikallinen kulttuuri heijasteli yleiseurooppalaisia aatteita ja virtauksia. Uutuudet - oli kyseessä julkisen tai yksityisen rakentamisen, asumisen tai kulutuksen tyyli - edustivat kulttuurin tuontia ja soveltamista Viipu-

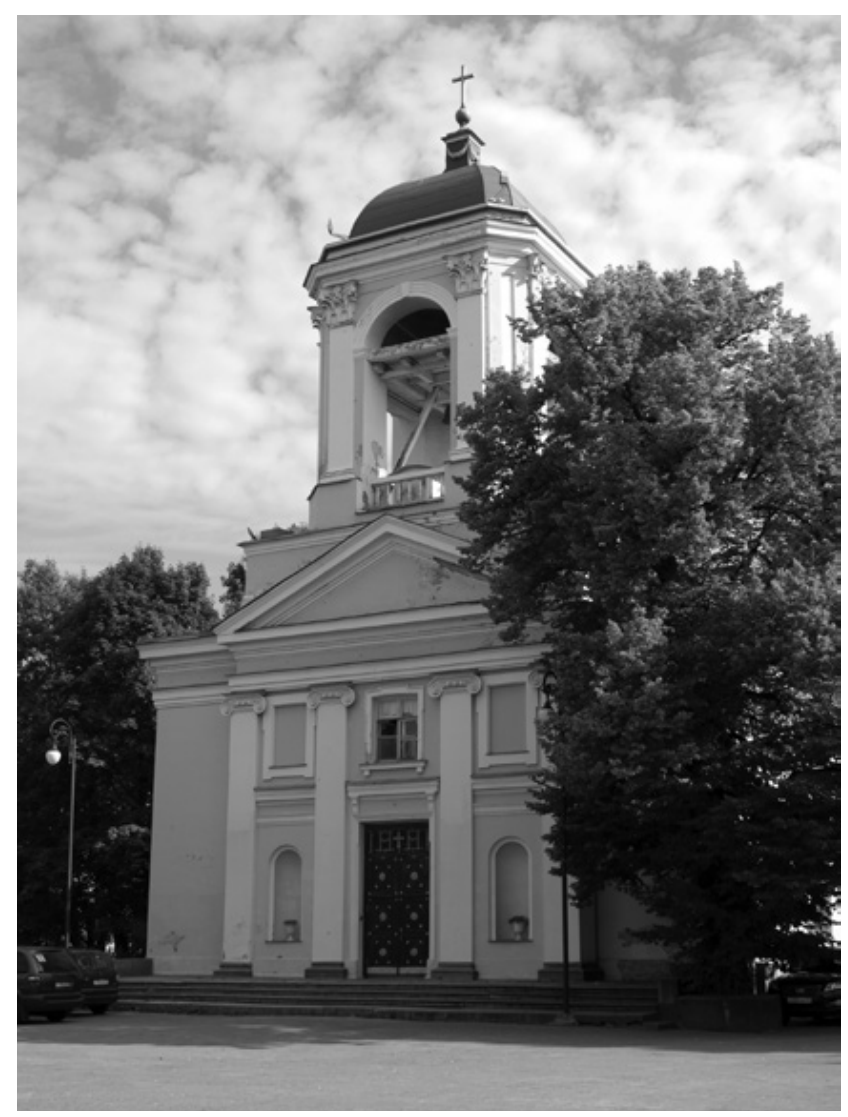

Saksalais-ruotsalaisen seurakunnan uusklassinen Pietarin-Paavalin kirkko. riin. Ilmiöt rantautuivat joko suoraan saksankielisestä maailmasta tai suodattuneina Baltian provinssien tai Pietarin saksalaispiirien välityksellä. Yhteys Ruotsiin tai rajantakaiseen Suomeen oli tässä yhteydessä - ehkä evankelis-luterilaista kirkollista kulttuuria lukuun ottamatta - varsin merkityksetön. Kulttuurin eri muotojen reseptio, vastaanotto, hyväksyminen ja paikallinen muuntuminen olisi tässä suhteessa mielenkiintoinen prosessi tutkittavaksi.

Esimerkiksi 176o-luvulla alkanut arkkitehtuurin tyylinmuutos uusklassiseksi koski koko Venäjää. Ajan virtauksia pyrittiin tältä oin seuraamaan Viipurissakin, mutta akateemista huipputasoa edustavien arkkitehtien (Giacomo Quarenghi, Nikolai Lvov tai Georg von Veldten) suunnitelmia joko muutettiin, yksinkertaistettiin tai jätettiin Viipurissa eri syistä puolitiehen. Samoin valtakunnallisia sotilasrakennusten 1770-luvulla tehtyjä, sitoviksi tarkoitettuja mallipiirustuksia toteutettiin Vanhan Suomen linnoituspaikkakunnilla poikkeuksetta paikallisin muunnoksin, vaikka hahmo ja tyylin peruspiirteet olivat tunnistettavissa yleisvenäläisiksi.

Viipuria vuonna 1793 tuhonneen tulipalon jälkeen valtakunnallinen kaupun- 
kien rakennuskomissio antoi arkkitehti Quarenghin tehtäväksi suunnitella kaupunkiin julkiset rakennukset, mutta useimmat jäivät vain paperille. Kuvernementin hallintovirastoja ja oikeuslaitosta varten tarkoitetun korttelin rakentamista ei ehditty aloittaa ennen kuin uusi keisari Paavali I alkoi vuoden 1796 jälkeen perua kaikkia edeltäjänsä Katariina II:n aikaisia reformeja. Komeaksi suunnitellusta kaksikerroksisesta, hevosenkengän muotoisesta kauppahallista, gostinnyi dvorista, valmistui vain vajaa puolikas ja sekin yksikerroksisena. Pietarin monumentaalirakennuksia suunnitellut Georg von Veldten (1730-1801) korjaili ja Viipurin saksalais-ruotsalaisen seurakunnan uuden kirkon piirustuksia, jotka kuvernementinarkkitehti Johan Brockmann oli laatinut. Kyseinen Pietari-Paavalin kirkko valmistui vuonna 1799 suurin piirtein Pietarissa viimeisteltyjen piirustusten mukaisesti, mutta pyhätön molemmin puolin suunnitellut koulu- ja konsistorirakennukset jäivät rakentamatta.

\section{KANSAINVÄLISEN TUTKIMUKSEN INSPIROIMIA TUTKIMUSTEHTÄVIÄ}

Viipurin Vanhan Suomen aikainen kulttuurielämä - kulttuuri tässä laajasti ymmärrettynä - on ollut Suomessa ja Venäjällä systemaattisen tutkimuksen kohteena runsaan sadan vuoden ajan, Gabriel Laguksen historiakoosteesta ja J. W. Ruuthin kaupunkihistoriasta alkaen. Kuten aiemmin esitetystä on käynyt ilmi, tutkimus on jatkunut sekä suomalais- että venäläisvoimin jo Ruuthin aikanaan määrittämillä osa-alueilla. Empiirisesti painottunutta tutkimustietoa on karttunut etenkin kolmesta teemakokonaisuudesta: 1) kirkolliset olot, kirkot, papisto ja koulujärjestelmä, 2) kaupungin rakentuminen, asemakaavat ja julkiset rakennukset sekä 3) henkilö- ja sukuhistoria.

Varsinkin 1990-luvulta eteenpäin on sekä Suomessa että Venäjällä tutkittu erityisesti Monrepos'n kartanoa sekä sen puistoa, kirjastoa ja muita kokoelmia sekä henkilöhistoriaa 170o-luvun valistuskulttuurin ja "esiromantiikan" laajemmassa, vertailevassa viitekehyksessä. Myös muutamia muita 1700-180o-lukujen kulttuurihistorian erityiskysymyksiä on selvitetty perusteellisesti. Näihin kuuluvat kaupungin teatterihistoria sekä saksankielinen kirjallinen tuotanto Viipurissa vuonna 1805 perustetun lyseon vaikutuspiirissä. ${ }^{39}$

Millaisia tutkimustehtäviä tulevalle Vanhan Suomen ajan kaupunkikulttuuria käsittelevälle tutkimukselle voisi asettaa? Lisäselvittämistä kaipaavat edelleen Viipurin kulttuurikentän muodonmuutokset 1700-luvulla ja niiden sovittaminen vuoden 1812 jälkeiseen uuteen valtiolliseen tilanteeseen Suomen suuriruhtinaskunnan osana: kuinka virallisesti venäläinen, joskaan ei venäjänkielinen kuvernementinkaupunki muuntui suomalaiseksi läänin residenssikaupungiksi? Aihetta tutkittaessa Viipurin kuvernementin muut kaupungit Hamina, Käkisalmi, 
Lappeenranta, Savonlinna ja Sortavala muodostaisivat Viipurille kulttuurisesti lähimmän vertailukohteen. Näiden kaupunkien 1700- ja 1800-luvun kulttuurin tutkimus on Viipurin tavoin korostanut kansallisuuspiirteitä, kieliryhmiä ja venäläis-suomalaisia konfliktitilanteita. Kaikki mainitut pienet kaupungit olivat sangen yhtenäisen saksalaisvoittoisen, Pietarissa ja Itämeren provinsseissa voimakkaana kukoistaneen urbaanin kulttuurin paikallismuunnoksia.

Vanhan Suomen kaupungeissa käytettiin sekä kahta "maankieltä" (Landessprachen) eli suomea ja ruotsia valtakunnankieli venäjän ja sivistyskieli saksan rinnalla, mutta kaikkia eri yhteyksissä ja vaihtelevissa suhteissa. Moninaisten ja muuttuvien määräysten mukaisesti hallinto- ja oikeusasioissa käytettiin virkakielenä venäjää, saksaa ja ruotsia. Kirkon piirissä toimittiin ruotsiksi ja saksaksi, mutta jumalanpalvelusten ja toimitusten kielenä oli luterilaisten seurakuntien jäsenten enemmistön kieli suomi. Itämeren provinsseissa eli Viron-, Liivin- ja Kuurinmaan kuvernementeissä käytettiin niin ikään saksaa ja venäjää ja vastaavalla tavoin paikallisia "maankieliä".

Uusia vaikutteita Viipuri-tutkimukseen on syytä etsiä myös venäläisestä historiankirjoituksesta. Venäjän valtakunnan 1700-luvun kulttuurihistorian tutkimuksessa on viime vuosina ja vuosikymmeninä noussut esille Viipuriinkin sovellettavissa olevia lähestymistapoja ja tutkimusongelmien kokonaisuuksia. Monikansallisten valtioiden historiallinen ja kulttuurinen "dekonstruktio" niiden "konstruktiota", muodostumista ja rakentumista tutkimalla sisältää aina kannanottoja kansallisten näkökulmien soveltamisen historiaan, mikä merkitsee samalla yksinkertaisen kansallisen tulkintamallin uudistamista. Kokonaisia valtioita ja suurkaupunkeja koskevat moninaisuuden periaatteet voidaan ulottaa mikro- ja henkilötasolle myös pientä provinssikaupunkia tutkittaessa. ${ }^{40}$ Hedelmällinen aihe voisi olla esimerkiksi Viipurin 170o-luvun porvariston maailma suku-ja henkilöhistorian verkoston puitteissa - siinä näkyvät kaikki Vielvölkerreichin ilmiöt, kieli-ja sosiaalihistoria sekä konkreettinen, maantieteellinen liikkuvuus.

Postkolonialistiseksi kutsuttu historiantutkimuksen suuntaus on jo pitkään luonut tärkeän kulttuurihistoriallisen lähtökohdan sekä suurvaltojen horisontista että entisten siirtomaavaltojen nousuun ja tuhoon liittyvistä "kulttuurisista kohtaamisista" (encountering). Kolonialismiin liittyviä kulttuurisia ja taloudellisia valtapyrkimyksiä ja niiden aatemaailmaa on nähty myös Venäjän sisäisessä historiassa. Esimerkiksi Alexander Etkindin tutkimukset Venäjän ja myöhemmin Neuvostoliiton historiasta eräänlaisena siirtomaavaltana eli jatkuvana oman maan ja valloitettujen alueiden kolonisaationa ovat herättäneet runsaasti huomiota. ${ }^{41}$ Kolonisaatioon liittyvät kysymykset valloituksista ja niiden seurauksista sekä valloitettujen alueiden väestön, kulttuurin, uskonnon ja kielen asemasta. Tässä mielessä Viipuri oli yhden Venäjän 170o-luvulla 
valloittaman uuden "siirtomaan", Vanhan Suomen, pääkaupunki. Kaupungin historiaa olisi mahdollista tutkia tällaisestakin yleisperspektiivistä käsin.

Venäjällä 1960-luvulla muodostunut laaja kulttuurisemiotiikan tutkimusperinne, joka rakentui kirjallisuuden ja taiteen tarjoamien historiallisten "tekstien” ympärille, ei ole yleisessä kulttuurihistoriassa juurtunut Suomeen. Viipuri olisi kiinnostava kohde tunnuskuvien ja symbolien, seremonioiden ja kirjallisten teosten tutkimiselle kulttuurisemioottisesta näkökulmasta, koska kaupungin menneisyysestä hahmottuu julkisen ja yksityisen tai paikallisen ja yleisvaltakunnallisen välistä kilpailuasetelmaa ja historiaa eri tavoin hyväksikäyttävää "sisällöntuotantoa". Jo 170o-luvulla virisi kiinnostus myös kaupungin näkyviä historiallisia muistomerkkejä ja historiankirjoitusta kohtaan, ja jo tällöin linna oli kaupungin itseoikeutettu tunnuskuva. Taiteilijat, kirjailijat ja koti- ja ulkomaisten matkailijoiden kertomukset tuottivat "Viipuri-tekstejä", joiden järjestelmällinen tutkiminen on vielä tekemättä. ${ }^{42}$ Venäjällä suositun "kulturologian" akateeminen, syntetisoiva lähestymistapa on Suomessa jäänyt varsin vähälle huomiolle. Tila, kaupunkitila ja sen eri muunnelmat ja niiden merkitykset ovat kulturologian keskeisiä tutkimuskohteita, jotka laajentavat puhtaan arkkitehtuuri- ja rakentamishistorian ulottuvuuksia. Tällaisia näkökulmia pyrkii yhdistämään Kimmo Katajalan johtama, Suomen Akatemian rahoittama hanke Meanings of an Urban Space, Past and Present. Cross-cultural studies of the Town of Vyborg from the $16^{\text {th }}$ to the $21^{\text {th }}$ Century.

Kansainvälisessä paikallishistoriallisessa tutkimuksessa on elvytetty saksalaisen Justus Möserin alkuaan Osnabrückin kaupungin historiassaan (1. painos 1768) esittämä käsite Lokalvernunft, paikallisjärki. Sen vastaparin muodosti Universalvernunft, yleisjärki, joka viittasi valistuskauden järkiuskon abstrakteihin käsitteisiin, poliittis-yhteiskunnalliseen teorianmuodostukseen tai lainsäädännön kirjaimeen. Paikallisjärki ohjasi todellisia tapahtumia, kaupunkien instituutioita ja henkilöitä tietyissä oloissa ja tiettynä aikana. Möserin mallin mukaan paikallista historiallista todellisuutta olisi tutkittava ja ymmärrettävä kokonaisvaltaisesti ja jatkuvana vuorovaikutuksena eristämättä mitään osa-aluetta tai ryhmää erilliseksi kohteeksi. "Vapauden" kaltaiset abstraktit käsitteet eivät vaikuttaneet sellaisenaan mihinkään, vaan olivat ainoastaan todellisten henkilöiden ja näiden kokemien tapahtumien taustatekijöitä.

Paikallisjärki muotoutui maantieteellisessä yhteydessään ja paikallisessa kontaktipiirissä kulttuurisen vuorovaikutuksen tuloksena. Viipurilla oli lähialueensa: kuvernementti ja sen muut kaupungit. Sen ulkolähialueen muodostivat pääkaupunki ja Inkerinmaa sekä lähimmät Itämerenmaakunnat Viro ja Liivinmaa saksanvoittoisine kaupunkeineen sekä Ruotsin Suomen puoleinen osa. Näistä seurannut konkreettisten yhteyksien vyöhyke kattoi jo yksin kaupan 
ja merenkulun ansiosta lähes koko Itämeren eteläosan ja sitäkin kaukaisemmat maat, kuten Tanskan ja Hollannin.

Aatteellinen, kirjallinen ja tieteellinen yhteyksien vyöhyke oli vieläkin laajempi, jos otetaan lukuun esimerkiksi viipurilaisen ylimmän porvariston poikien opiskelupaikkakunnat 170o-luvulla: Turun ja Upsalan lisäksi lähdettiin myös Saksan parhaimpiin yliopistoihin, Göttingeniin, Jenaan, Halleen tai Kieliin. Vastavuoroisesti "Viipurin romantiikan" kauden johtohenkilöt, saksankielisen lyseon opettajat 1810-luvulle saakka, tulivat samoista opinahjoista. Opettajien Viipurissa vietetyt vuodet sijoittuivat tyypillisesti uran alkuvaiheisiin ja niitä seurasivat toiset opettajantoimet Itämeren provinsseissa tai Pietarin saksankielisissä kouluissa.

Yliopisto-opintojen molemminpuolista vaikutuspiiriä myös rajattiin poliittisin perustein. Vuonna 1798 keisari Paavali kielsi Venäjän alamaisten opinnot ulkomaisissa yliopistoissa ja esimerkiksi Turusta muutamat Viipurilaisen osakunnan jäsenet palasivat kotiinsa. Vuoden 1802 jälkeisessä Aleksanteri I:n opetuslaitosreformissa Venäjän jaettiin yliopistojen johtamiin opetuspiireihin. Viipurin ja kuvernementin muiden paikkakuntien julkiset koulut luettiin Tarton uuden yliopiston yhteyteen perustetun komission alaisiksi, ja Viipurin vuonna 1805 perustetun kymnaasin oppilaiden edellytettiin jatkavan opintojaan ylioppilaina Tartossa.

Vanhan Suomen aikaisen Viipurin kulttuurin ulottuvuudet ovat niin maantieteellisesti kuin aatteiden, tieteiden tai taiteiden näkökulmasta huomattavan laajoja. Myös molemmilla suurilla kirkkokunnilla oli oma taustamaantieteensä, joka heijastui sekä henkilöhistoriaan että hallintoon ja henkiseen ilmapiiriin. Luterilaiseen papistoon kuului osin paikallisia pappissukuja, mutta täydennystä saatiin usein Ruotsin puolelta ja Saksan yliopistoista. Venäläinen papisto työskenteli puolestaan Pietarin metropoliitan sekä Pyhän Synodin alaisuudessa ja oli sidoksissa oman kirkkonsa pappiskoulutukseen ja perinteisiin. Lisäksi Viipuri oli koko 170o-luvun ajan sotilaallisesti aktiivikäytössä oleva linnoituskaupunki. Sellaisena se oli osa suurta valtakunnallista puolustuslaitosten, asevoimien ja sen sisäisen kulttuurin tarkoin normittamaa, univormuun puettua verkostoa.

Maallisten, henkisten, hallinnollisten ja sotilaallisten kulttuurien muodot kohtaavat Viipurissa; ne toteutuvat ja muuntuvat paikallisesti kaupungin asukkaiden toimissa ja heidän omassa aikahorisontissaan. Tutkijoiden aikahorisontti on toinen ja tutkimuskysymykset muotoutuvat historioitsijan omasta ajasta käsin. Viipurin paikallisen kulttuurimuodon tutkiminen ja sen monipuolinen ymmärtäminen oman aikakautensa, 1700-luvun historian, ilmaisuna on ollut ja on Suomen ja Venäjän historian tutkimuksen näkökulmasta harvinaisen antoisa tehtävä. Näin voi olla tulevaisuudessakin, mikäli aikakauteen kuulumattomasta kansallisuusajattelusta on nyt lähtökohtaisesti luovuttu. ${ }^{43}$ 


\section{Viitteet}

1 Von Knorring 1833.

2 G. Lagus 1893; G. Lagus 1895.

3 Ahrenbergin restaurointisuunnitelmista: Ripatti 2011.

4 Ruuth 1906; Ruuth 1908.

5 Borodkin 1909.

6 Vikstedt 1926.

7 Raijanen 1940.

8 Porthanin käsityksistä: E. Lagus 1898. (Kirje Nils von Rosensteinille 22.7.1793); Takolander 1926.

9 Tigerstedt 1940; Tigerstedt 1952.

10 Nikander et al. 1929; O. Paavolainen 1940; Viiste 1943.

11 Nissilä 1953.

12 Y. Blomstedt 1949.

13 Lundén Cronström \& Hornborg 1961.

14 Hirn 1959.

15 Hirn 1970.

16 Katso teatteriseurueista: Tässä kokoelmassa Wolff, 51-53; Paavolainen 61-65.

17 Kuujo \& Ruuth 1975.

18 Meurman 1977; Meurman 1983.

19 Väänänen 1975a; Väänänen 1975b.

20 Knapas 1998, Knapas 2013; Kauppi 1993; Suhonen 2011.

21 Küttner 1986; Küttner 1988.

22 Tarkemmin: Shikalov tässä kokoelmassa, 248.

23 Kauppi \& Miltšik 1993.

24 Schweitzer 1993; Schweitzer 1996; Thieme 2012.
25 Ruoff 1993.

26 Knapas 2003.

27 C. J. Gardberg \& Welin 1996.

28 Neuvonen, Pöyhiä, \& Mustonen 1999; Neuvonen 1994; Neuvonen 2008.

29 Väänänen 1987; Väänänen \& Luther 2002.

30 Kotivuori 2005

31 ljäs 2015.

32 Esim. Kepp 1977.

33 Kepp 1992.

34 Lihačov 1982.

35 Lihačov 1984.

36 Efimov \& Mošnik 2010

37 Trohova 2007.

38 Kaukiainen, Marjomaa, \& Nurmiainen 2013.

39 Hirn 1959; Hirn 1970; Schweitzer 1996. Myös Schweitzerin toimittama: Thieme 2012.

40 Kappeler 1992.

41 esim. Ėtkind 2011.

42 Tällaista tutkimusta on tosin hiljattain käynnistänyt Yury Shikalov: esim. artikkeli tässä kokoelmassa, 243 alkaen.

43 Parppei 2011; Suutari 2013; Knapas 2015. Ajatusta Karjalan alueista osana kansallisvaltioita suuremman Itämeren kulttuuripiirin osana voidaan pitää vakiintuneena: tässä kokoelmassa, 12-13. 